\title{
Blind comparison of Abbott and Dupont HIV antigen ELISA tests for detecting antigenaemia in asymptomatic human immunodeficiency virus antibody positive homosexual men
}

\author{
D C Shanson, K E Brown, S Goonesekera, B Gazzard, A R M Coates
}

\begin{abstract}
Three hundred and ninety eight serum samples from 270 human immunodeficiency virus (HIV) antibody positive asymptomatic homosexual men were tested in the Abbott and Dupont HIV antigen ELISA tests. In the Abbott test 62 $(16 \%)$ of the sera were positive, according to the manufacturer's instructions, compared with $55(14 \%)$ in the Dupont test. Twenty six sera were positive with the Abbott test but negative with the Dupont test and 19 sera were positive only by the Dupont test. Only $36(9 \%)$ of the sera were positive in both tests. The Abbott confirmatory neutralisation test gave excellent agreement with the initial Abbott HIV antigen ELISA test; the Dupont confirmatory test was only in agreement with the initial positive Dupont antigen ELISA test in one third of the sera tested. Although the overall sensitivity of each of the two commercial assays tested was similar, the Abbott method may be preferable for clinical purposes if confirmation of an initial ELISA positive test result by neutralisation assay is required.
\end{abstract}

Human immunodeficiency virus (HIV) antigen tests are used to monitor patients with HIV infection who are receiving antiviral treatment. ${ }^{1-3}$ They have been recommended as a useful index for initiating treatment. ${ }^{4}$ HIV antigen can also be detected in the serum before antibody seroconversion, but it then disappears in most cases as antibody titres rise. ${ }^{5}$ Patients who do not lose their HIV antigenaemia have been shown to be at greater risk of developing AIDS. ${ }^{6-8}$ Two commercially available HIV antigen enzyme linked immunosorbent assay (ELISA) tests (Abbott HTLVIII Antigen test and DuPont HIV p24 Antigen test) are widely used. In this study serum samples from asymptomatic patients with HIV infection were investigated for HIV antigen by both these tests. There was only "fair" agreement between the results of the two tests.

\section{Methods}

Between September 1987 and May 1988 all HIV antibody positive homosexual men attending the sexually transmitted disease clinic at St Stephen's Hospital, Chelsea, were assessed, and those classified as the "CDC group 2" stage-that is, asymptomatic HIV infection ${ }^{9}$-were asked to contribute a specimen of blood for antigen tests. Three hundred and ninety eight specimens were obtained from 270 men. The samples were separated immediately and stored at $-20^{\circ} \mathrm{C}$ until tested.

\section{ABBOTT HIV ANTIGEN ASSAY}

All the Abbott HIV antigen assays were carried out at St Stephen's Hospital where the results of the DuPont HIV Antigen assay were unknown. The sera were tested in the Abbott HTLV Antigen EIA (Abbott Laboratories, North Chicago, Illinois, USA) according to the manufacturer's instruction sheet. For each test a bead coated with human anti-HIV was added to $200 \mu \mathrm{l}$ of serum and incubated overnight at room temperature. The beads were washed in distilled deionised water using Pro-Quantum (Abbott Laboratories) and reincubated with $200 \mu \mathrm{l}$ of rabbit anti-HIV, for four hours at $40^{\circ} \mathrm{C}$. After a final wash the beads were incubated with $200 \mu \mathrm{l}$ of goat anti-rabbit horseradish peroxidase conjugate for two hours at $40^{\circ} \mathrm{C}$. After the final wash the beads were transferred to tubes, $300 \mu \mathrm{l}$ of substrate O-Phenyldiamine HCL (OPD) added, and the tubes incubated in the dark. The colour development was stopped after 30 minutes by the addition of $1 \mathrm{ml} 1 \mathrm{M}$ $\mathrm{H}_{2} \mathrm{SO}_{4}$, and the absorbance at $492 \mathrm{~nm}$ read using a Quantum Dual Wavelength spectrophotometer (Abbott Laboratories). A sample was regarded as positive if the optical density (OD) was greater than the cut off OD $(0.05$ plus the mean negative control OD).

The positive and equivocal sera (serum volumes permitting) were retested using the Abbott confirmatory test (Abbott HTLV III Antigen Neutralisation Test). In this test $200 \mu \mathrm{l}$ of sample were preincubated with either $50 \mu \mathrm{l}$ of Neutralisation Reagent (neutralised sample) or $50 \mu \mathrm{l}$ of Control Reagent (control sample) for two hours at room temperature. After this a bead coated in human anti-HIV was added to each sample and the assay continued as for the HIV antigen test. Samples were considered to be confirmed positive if the control sample OD was greater than the mean negative control plus 0.04 and the reduction in the absorbance 
of the neutralised sample compared with that of the control sample was greater than $50 \%$.

DUPONT HIV ANTIGEN ASSAY

All the DuPont HIV antigen assays were tested at the London Hospital Medical College where the results of the Abbott antigen assay were unknown. The sera were tested in the DuPont HIV p24 core antigen ELISA NEK-046 (EI Du Pont de Nemours and Co, Wilmington, Delaware, USA) according to the manufacturer's instruction sheet. The microtitre wells, coated with rabbit polyclonal anti-p24, were washed six times with the wash fluid provided, and incubated overnight with $200 \mu \mathrm{l}$ of each specimen, mixed with $20 \mu \mathrm{l}$ of $0.5 \%$ Triton X-100. The wells were rewashed six times and further incubated with $100 \mu \mathrm{l}$ of biotinylated rabbit anti-p24 for two hours at $37^{\circ} \mathrm{C}$. After six further washes the antibody-antigen-antibody complex was probed by incubating with $100 \mu \mathrm{l}$ of streptavidin-horseradish peroxidase conjugate for 30 minutes at $37^{\circ} \mathrm{C}$. After a final wash $100 \mu \mathrm{l}$ of substrate, (OPD), were added to each well, and the colour allowed to develop over 30 minutes, in the dark, at room temperature. The reaction was stopped by adding $100 \mu \mathrm{l}$ of $\mathrm{IM} \mathrm{H}_{2} \mathrm{SO}_{4}$, and the absorbance at $492 \mathrm{~nm}$ was measured using a dual wavelength plate spectrophotometer (Dynatech MR 600) with a reference filter at $620 \mathrm{~nm}$. The results were regarded as positive if the $O D$ was greater than the reactive threshold value (mean negative control OD plus $0 \cdot 1$ ).

The positive and equivocal sera were retested using the DuPont confirmatory assay (DuPont) HIV p24 core antigen confirmatory assay A-112). In this assay $225 \mu \mathrm{l}$ of each sample were preincubated at $37^{\circ} \mathrm{C}$ for $30 \mathrm{~min}$ utes with $25 \mu \mathrm{l}$ of $5 \%$ Triton X-100 and of either $10 \mu \mathrm{l}$ of the confirmatory reagent (neutralised sample) or $10 \mu \mathrm{l}$ of the control reagent (control sample). After incubation $200 \mu \mathrm{l}$ of each mixture were added to each well of a prewashed HIV p24 antigen plate and the antigen assay continued as above. A result was positive in the confirmatory assay if the control sample OD was greater than the mean negative control plus 0.08 and the reduction in the absorbance of the neutralised sample compared with that of the control sample 7 was greater than $50 \%$.

Various indices of agreement are available, but the $\kappa$ index was chosen as it corrects for chance agreement between the assays. It takes the value of 1 when there is complete

Table 1 Comparison of results of initial testing of 398 HIV antibody positive sera by both ELISA tests

\begin{tabular}{|c|c|c|c|}
\hline & \multicolumn{2}{|c|}{ Dupont ELISA results } & \\
\hline & Positive & Negative & \\
\hline $\begin{array}{l}\text { Abbott ELISA results } \\
\text { Positive } \\
\text { Negative }\end{array}$ & $\begin{array}{l}36 \\
19 \\
55 \text { Total } \\
\text { Dupont } \\
\text { positive }\end{array}$ & $\begin{array}{l}26 \\
317 \\
343 \text { Total } \\
\text { Dupont } \\
\text { negative }\end{array}$ & $\begin{array}{l}\text { Total } \\
622 \text { Abbott positive } \\
336 \text { Abbott negative }\end{array}$ \\
\hline
\end{tabular}

Table 2 Comprison of results of repeat testing and confirmatory assays of both ELISA tests

\begin{tabular}{lcc}
\hline Repeat testing & Abbott & DuPont \\
\hline $\begin{array}{l}\text { Positive on repeat testing/number } \\
\text { of initial positive sera retested }\end{array}$ & $53 / 54$ & $52 / 53$ \\
$\begin{array}{l}\text { Confirmation by neutralisation test : } \\
\text { Positive on confirmatory } \\
\text { testing/number of initial ELISA } \\
\text { positive sera tested }\end{array}$ & $53 / 53$ & $15 / 46$ \\
\hline
\end{tabular}

agreement. ${ }^{10}$ Further details are available from the authors.

\section{Results}

The results of initial testing the sera in the individual HIV ELISAs are shown in table 1. In the Abbott test 62 of $398(16 \%)$ sera were positive compared with 55 of $398(14 \%)$ sera in the Dupont ELISA test. Only 36 of $398(9 \%)$ sera gave positive results in both tests. Twenty six sera were positive with the Abbott test but negative with the Dupont test, and 19 sera were only positive by the Dupont test. The $\kappa$ statistic only indicated "fair" agreement between the two tests $(\kappa=0.549$, standard error $(\kappa)=$ $0.050, \mathrm{z}=10.9 ; \mathrm{p}<0.001)$.

Both tests gave similar results on retesting the sera (table 2). The Dupont test gave poor correlation with the initial ELISA test as only 15 of $46\left(33^{\circ}{ }_{0}\right)$ initial Dupont positive results were confirmed. In contrast, the Abbott confirmatory test confirmed 53 of 53 of the initial Abbott positive ELISA results. There were insufficient volumes of serum for Abbott neutralisation tests on nine samples.

Discrepant results were observed for a group of 18 sera which on initial testing were positive by the Dupont test but negative by the Abbott test. On confirmatory tests only one of the 18 sera was neutralised in the Dupont confirmatory test whereas the group that was both Dupont and Abbott positive on initial testing yielded 13 positive Dupont confirmatory results out of 30 tested.

\section{Discussion}

The overall sensitivities of the initial testing with Abbott and Dupont tests were similar, but there were great differences in the results obtained with individual patients. In the Abbott ELISA 62 of the sera from 44 men were positive, compared with 55 positive sera from 37 men in the Dupont test. Thus the prevalence of antigenaemia in the 270 patients investigated in this study was $16 \%$ with the Abbott ELISA and $14^{\circ}{ }^{\circ}$ with the Dupont test and is similar to that obtained in other studies. These range from $5^{\circ}$ in asymptomatic Dutch patients (Abbott test) ${ }^{11}$ to $19 \%$ in an American study (Abbott test). ${ }^{12}$ The figures may vary with the type of subpopulation being studied, such as homosexual, haemophilic, or those with disease transmitted through blood products, and especially with the ethnic background of the patients being studied. ${ }^{13}{ }^{14}$ In Boston six of 47 $(13 \%)$ of asymptomatic HIV antibody positive homosexual men had antigenaemia by the Abbott test. ${ }^{12}$ In Pittsburg HIV antigenaemia 
occurred in eight of $52(15.4 \%)$ subjects during the first 12 months after HIV antibody seroconversion. ${ }^{15}$

Although there are limited data on the relative sensitivities of the two ELISAs for the detection of antigenaemia, several studies have looked at the ability of the two tests to detect antigen in cell culture supernatant. Jackson $e t$ al evaluated the Abbott and DuPont antigen ELISA and found that the Abbott test detected antigen earlier (mean 6.2 days compared with mean $7 \cdot 4$ days for the DuPont). ${ }^{16}$ The DuPont ELISA, however, was modified in December 1987 , and it is not clear whether the original or modified ELISA was used in their study. Healey et al, using the original HIV antigen test, showed that the DuPont could detect 70 $\mathrm{pg} / \mathrm{ml} \mathrm{HIV} \mathrm{protein} \mathrm{(about} 18 \mathrm{pg} / \mathrm{ml} \mathrm{p} 24){ }^{17}$ whereas the Abbott test was slightly less sensitive and had a detection rate of $130 \mathrm{pg} / \mathrm{ml}$ (35 $\mathrm{pg} / \mathrm{ml}$ ). The results of the present study suggest that the Abbott test was more sensitive, in keeping with the findings of others who looked at the sensitivity of the two tests on serum samples (Abstracts presented to Fourth International Conference on AIDS, Stockholm, 1988).

There were many obvious differences between the results of initial Abbott and Dupont tests on individual patients. Only 36 of the 398 $\left(9^{\circ}{ }_{0}\right) \mathrm{HIV}$ antibody positive sera tested were HIV antigen positive in both tests, while 62 $\left(16^{\circ}{ }_{0}\right)$ and $55(14 \%)$ were positive in the Abbott and Dupont tests, respectively. This is clinically unsatisfactory-for instance, if the HIV antigen test were to be used as one of the variables for the start of drug treatment of HIV infection in asymptomatic patients different patients might receive treatment depending on whether the Abbott or Dupont tests were used. One possible explanation for the discrepant results between these two tests could be that each test detects somewhat different HIV epitopes. From the manufacturer's data sheet, the Dupont ELISA should just detect p24, whereas the Abbott ELISA, using a polyclonal antibody against whole HIV, may detect other antigenic proteins as well as p24.

Major disrepancies were also observed between the results of the Abbott and Dupont confirmatory assays. In the Abbott HIV ELISA $100^{\circ}{ }_{0}$ of the initial positive sera were confirmed positive in the Abbott neutralisation test whereas only $33 \%$ of the initial Dupont antigen positive sera were confirmed positive by the Dupont neutralisation test. Moreover, only one of 18 sera only initially positive by the Dupont antigen test was confirmed positive by the Dupont neutralisation test; nearly half the sera that were initially positive by both the Abbott and Dupont tests were confirmed positive by the Dupont neutralisation test. The clinical importance of Dupont positive HIV antigen results in sera where the Dupont confirmatory assay result is negative is unclear. The Dupont confirmatory test only required 10 $\mu \mathrm{l}$ of antibody solution incubated for $30 \mathrm{~min}$ utes with the serum sample. This confirmatory technique may not be adequate for neutralisation of the HIV antigen, or the Dupont HIV initial assay may be capable of detecting the antibody-antigen complexes. The reason why some other sera gave confirmed positive HIV Abbott antigen test results but completely negative Dupont antigen test results could have been that the Abbott antibody system also binds to HIV proteins other than p24 while the Dupont detector antibody was specific for p24 alone.

The results of this study raise the clinically relevant question as to whether one or two different commercial tests should be used when an HIV antigen test is requested as the use of only one test method will "miss" a significant number of positive results detected by the other method. Ideally, both Abbott and Dupont antigen test results would be given for each serum, but this policy would be both technically labour intensive as well as expensive. Even if both tests were to be used there would be occasional problems in interpreting the results as we are not sure why the tests sometimes give different results. In our opinion the serum reacting as positive by both tests could be regarded as a true positive result, while a sample reacting positive by the Abbott test alone could be regarded as a positive result, although with rather less conviction. A sample positive by the DuPont test alone-that is, no confirmation forthcoming, cannot be regarded as positive from the point of view of clinical evaluation until further information is available about the clinical importance of an Abbott negative/DuPont positive test. If only one commercial assay is used it is clearly desirable to use a test where a positive result can also be confirmed by a neutralisation test-thus the Abbott method may be preferable to the Dupont test in this regard.

We are grateful to Dr A J Nunn for help and advice with statistical analysis and to Farmitalia Carlo Erba for financial support.

1 Chaisson RE, Allain JE, Volberding PA. Significant changes in HIV antigen level in the serum of patients with azidothymidine. $N$ Engl J Med 1986;315:1610-11.

2 de Wolf F, Lange JMA, Goudsmit J, et al. Effect of zidovudine on serum human immunodeficiency virus antigen levels in symptom-free subjects. Lancet 1988;i: antigen

3 Schattenkerk JKME, Danner SA, Lange JMA, et al. Persistence of human immunodeficiency virus antigenaemia in patients with the acquired immune deficiency aemia in patients with the acquired immune deficiency syndrome treated with a reverse transcriptase
suramin. Arch Intern Med 1988;148:209-11.

4 Jackson GG, Paul DA, Falk LA, et al. Human immunodeficiency virus (HIV) antigenaemia (p24) in the acquired immunodeficiency syndrome (AIDS) and the effect of treatment with zidovudine (AZT). Ann Intern Med 1989;108:175-80

5 Goudsmit J, de Wolf F, Paul DA, et al. Expression of human immunodefiency virus antigen ( $\mathrm{HIV}-\mathrm{Ag}$ ) in serum and cerebral spinal fluid during acute and chronic infection. Lancet 1986:177-80.

6 Goudsmit J, Paul DA. Circulation of HIV antigen in blood accordng to stage of infection, risk group, age and accordng to stage of infection,
geographic origin. 1988;99:701-10.

7 Pederson C, Nielsen CM, Vestergaard BF, et al. Temporal relation of antigenaemia and loss of antibodies to core relation of antigenaemia and loss of antibodies to core antigens to development of clinical
tion. $B r$ Med J 1987;295:567-9.

8 Harry DI, Jennings MB, Yee J, Carlson JR. Antigen detection for human immunodeficiency virus. Clin Microbiol Rev 1989;2:241-9.

9 Centers for Disease Control. Classification system for human T-lymphotropic virus type $1 I I /$ lymphadenopathy associated virus infections. Morbid Mortal Week Rep 1986;35:334-9.

10 Fleiss JL. The measurement and control of misclassification error. In: Statistical methods for rates and proportion Chichester: J Wiley \& Sons, 1973.

11 Lange JMA, Paul DA, Hisman HG, et al. Persistent HIV antigenaemia and decline of HIV core antibodies 
associated with transition to AIDS. $\mathrm{Br}$ Med $\mathrm{J}$ 1986;293:1459-62.

12 Mayer KH, Falk LA, Paul DA, et al. Correlation of enzymelinked immunosorbent assays for serum human immunodeficiency virus antigen and antibodies to recombinant viral proteins with subsequent clinical outcomes in a cohort of asymptomatic homosexual men. $\mathrm{Am} \mathrm{J} \mathrm{Med}$ 1987;83:208-12.

13 Lelie PN, Reesink HW, Bakker E, et al. Clinical importance of HIV antigen and anti HIV core markers in persons infected with HIV. N Engl J Med 1988;318:1204-5.

14 Baillou A, Barin F, Allain JP, et al. Human immunodeficiency virus antigenaemia in patients with AIDS and AIDS-related disorders: A comparison between
European and central African populations. J Infect Dis 1987; 156:830-3

15 Rinaldo C, Kingsley L, Newmann J, Reed D, Gupta P, Lyter D. Association of human immunodeficiency virus (HIV) p24 antigenaemia with decrease in CD4 lymphocytes and onset of AIDS during the early phase of HIV infection. J Clin Microbiol 1989;27:880-4.

16 Jackson JB, Sannerud K, Rhame FS, Balfour HH. Evaluation of two commercial tests for human immunodeficiency virus antigens in culture supernatant fluid. Am J Clin Pathol 1988;89:788-90.

17 Healey DS, Maskill WJ, Neate EV, et al. A preliminary evaluation of five HIV antigen detection assays. J Virol Methods 1988;20:115-25. 